\title{
リモートセンシング画像解析ソフト “MultiSpec”（フリーウェア）の紹介
}

飯坂 譲二*

人工衛星から地球の環境情報や資源情報を観測する リモートセンシング技術が一般に知られるようになっ てから，30年近い年月が過ぎています。 21 世紀に入っ てその重要性はますます大きくなっていますが, この 間，日本でも独自の地球環境衛星を打ち上げたり，あ るいは, 独自のセンサーを開発し, 他国の人工衛星に 搭載したりして国際協力に貢献するようになっていま す。リモートセンシングは, 地球環境や地球資源情報 を専門的に研究・利用する機関や研究者を対象するば かりではなく,地方自治体やデベロッパーの意思決定， 小学校, 中学や高校を問わず, 学校で地理, 地球科学, 生態，歴史その他教育に役立つものです。

観測・収集されたリモートセンシングの画像デー夕 から地球環境や資源情報を抽出解析して役立てるに は,コンピュータを利用した解析が不可欠ですが，リ モートセンシングが日本に紹介された当時，ディジ夕 ル画像解析の重要性は認識されず，ディジタル画像は 不要とされた時代もありました。従って,リモ一ト七 ンシング画像のディジタル解析に必要なソフトウエア の開発·普及も他の IT 技術と同様, 国際的に大きな遅 れをとってしまっていることも事実です。幸い, 解析 に必要なコンピュータのハードウエアはこの 4 半世紀 の間，製造技術の進歩のおかげで PC でも処理できる ようになりました。しかし，リモートセンシング画像 の解析に必要なコンピュータのソフトウエアは多くの 商業化されたものがあるせよ，極めて高価で，リモー トセンシングを応用したり，試したりしたい人々に とって高值の花で, これが, 逆にリモートセンシング
の有効利用推進を阻んでいるといえます。

幸い,リモートセンシングのパイオニアであり,ディ ジタル解析の創世期からこの分野に寄与している米国 パデュー大学がNASA その他の機関の援助を受けて PCやマックで利用できる強力なソフトウエア“MultiSpec”®開発し, その普及のためにフリーウエアとし てWebからダウン・ロードできるように公開してい ます。

http://dynamo.ecn.purdue.edu/ ${ }^{2}$ biehl/MultiSpec/

このプログラムには, ランドサットの TM 画像のよ うな比較的バンド数の少ない画像のみでなく，ハイペ リオン画像のような200バンド近い多重分光画像の解 析が可能です。日本語版のメニューのプログラムは用 意されていませんが, ウィンドーのメニュー程度はリ モートセンシングに関心のある人たちには理解できる 程度の英語です。プログラムの手引書の日本語訳（訳 者 飯坂 譲二他) は, つくば市にある農林水産研究 センターにある下記の Web からダウンロードできま す。

http://www.affrc.go.jp/satellite/MultiSpec/

マックを利用する方は原著を参考にしてください。 プログラムは絶えず更新されているので，定期的なダ ウン・ロードを擢めします。

(編集委員会より：学会員に役立ちそうな,商用目的で ない無料のソフトウェアあるいはデータがありました ら学会編集委員会 (email : jsprs.soejima@nifty.ne.jp fax：03-3984-7402)までご連絡ください。案内を学会 誌に掲載いたします。) 